\title{
Limits and Limitations of Power: The Continued Relevance of Occupation Law
}

Afsah, Ebrahim

Published in:

German Law Journal

Publication date:

2006

Document version

Publisher's PDF, also known as Version of record

Citation for published version (APA):

Afsah, E. (2006). Limits and Limitations of Power: The Continued Relevance of Occupation Law. German Law Journal, 7(6), 563-590. 


\title{
ARTICLES
}

\section{Limits and Limitations of Power: The Continued Rele- vance of Occupation Law}

\author{
By Ebrahim Afsah*
}

\section{A. Introduction}

Lawyers are trained to apply rules to certain situations, and thus determining whether a particular behaviour is norm-conformant or not. It is generally assumed that rules as such exist and are applicable in a given situation. While there might be a debate about identifying the appropriate normative set among competing legal frameworks, it is generally taken as a given that binding rules exist and that they are habitually complied with. With regard to international relations, this basic ontological outlook contrast somewhat with the analytical conceptions taken by other disciplines which rely on other explanatory variables - notably power and interest - to account for the behavioural patterns of states.

In an influential review article the international lawyer Koh took up this extradisciplinary challenge, trying to answer the question as to why nations chose to fulfil international legal obligations. ${ }^{1}$ Those defending the notion that a body of fixed rules exists and that it is habitually complied with had to content with two main challenges: ${ }^{2}$ the 'realist' claim that whatever exists at the international level is not really law because it lacks the defining characteristic of enforceability, ${ }^{3}$ and the 'rationalistic' position that states only follow international rules as long as it serves their interests. Realists largely dismiss international law as secondary phenomena that are incapable of substantially affecting the calculations of power and interest

\footnotetext{
${ }^{*}$ Heidelberg/Amman. Email: eafsah@gmail.com.

${ }^{1}$ Harold Hongju Koh, Why Do Nations Obey International Law?, 106 YALE LAW JOURNAL 2599-659 (1997).

${ }^{2}$ Koh, Why Do Nations Obey International Law?, 106 YALE LAW JOURNAL (1997), 2602.

${ }^{3}$ For a general discussion see MALCOLM N. SHAW, INTERNATIONAL LAW (2003), chapter 1; Koh, Why Do Nations Obey International Law? 106 YALE LAW JOURNAL (1997), 2602, fn. 9; JOST DELBRÜCK (ED.), THE FUTURE OF INTERNATIONAL LAW ENFORCEMENT (1993); Josef L. Kunz, Sanctions in International Law, 54 AMERICAN JOURNAL OF INTERNATIONAL LAW 324-47 (1960); Peter J. Spiro, The New Sovereigntists: American Exceptionalism and Its False Prophets, FOREIGN AFFAIRS, no pagination (2000).
} 
that ultimately determine state behaviour. Rationalists are somewhat more accommodating towards empirical record of widespread rule adherence, ${ }^{4}$ but are in essential agreement that in the absence of a central enforcement mechanism considerations of power and interest will ultimately prevail: "since there is nobody to enforce the law, nations will comply with international law only if it is in their interest to do so; they will disregard law or obligation if the advantages of violation outweigh the advantages of observance." ${ }^{5}$

Such scepticism concerning the binding nature of law is even more pronounced with regard to the laws of war. ${ }^{6}$ Given the high stakes and the existential nature of the violence, it has been argued that the idea of imposing legal limits on the exercise of state violence is futile because since "[w]ar is an act of force, there is no logical limitation to the application of force." 7 This argument against idealistic legalism is firmly based on reason of state not a militaristic defence of untrammelled violence. Clausewitz' famous dictum about war as the continuation of politics by other means holds that "war is only a branch of political activity" and thus must not become an end in itself but has to serve political ends. ${ }^{8}$ The aim is thus not the destruction of the enemy but the inducement of a certain type of political behaviour to which end military violence is used. It is in this context that Clausewitz maintains that whatever limitation a war-fighting power submits to is not due to an altruistic normative commitment but the availability of more effective strategic or tactical means:

if civilised nations do not put their prisoners to death or devastate cities and countries, it is because intelligence plays a larger part in their methods [than was the case among savages] and has taught

${ }^{4}$ Reflected in the often-quoted statement by Henkin that "almost all nations observe almost all principles of international law and almost all of their obligations almost all of the time." LOUIS HENKIN, HOW NATIONS BEHAVE (1979), 47.

${ }^{5}$ Discussed in HENKIN, HOW NATIONS BEHAVE (1979), 49.

${ }^{6}$ Leslie C. Green, What Is - Why Is There - The Law of War?, ESSAYS ON THE MODERN LAW OF WAR (Leslie C. Green ed., 1999); Leslie C. Green, Cicero and Clausewitz or Quincy Wright? The Interplay of Law and War, ESSAYS ON THE MODERN LAW OF WAR (Leslie C. Green ed., 1999); LESLIE C. GREEN, THE CONTEMPORARY LAW OF ARMED CONFLICT (2000), chapter 1 and 2.

${ }^{7}$ CARL VON CLAUSEWITZ, ON WAR (1976), ch. 2, para. 90, ch. 1, para. 76. quoted in Leslie C. Green, What Is - Why Is There - The Law of War?, ESSAYS ON THE MODERN LAW OF WAR (Leslie C. Green ed., 1999), 1.

8 Carl von Clausewitz, The Political Purposes of War, BASIC TEXTS IN INTERNATIONAL RELATIONS (Evan Luard ed., 1992), 244. 
them more effective ways of using force than the crude expression of instinct. 9

Looking at the Iraq war from this angle, it is hard to argue that it has served either the professed or implied interests of the main belligerent powers particularly well. ${ }^{10}$ The issues concerning the decision to go to war have been exhaustively debated in the literature. ${ }^{11}$ The applicable ius in bello can usefully be divided into two periods: that of actual combat operations ending on 1 May 2003,12 and the subsequent period of occupation. The following observations are less concerned with specific legal questions relating to the proportionality and type of violence that arose in the context of actual combat operations, ${ }^{13}$ but focus on the occupation period, and in particular the legality of the political changes introduced by the Coalition Provisional Authority (CPA).

${ }^{9}$ VON CLAUSEWITZ, ON WAR (1976), ch. 2, para. 90, ch. 1, para. 76, emphasis added.

${ }^{10}$ Sir Michael Rose, Invasion a 'Blunder of Enormous Significance', THE GUARDIAN; LARRY DIAMOND, SQUANDERED VICTORY: THE AMERICAN OCCUPATION AND THE BUNGLED EFFORT TO BRING DEMOCRACY TO IRAQ (2005); DAVID PHILLIPS, LOOSING IRAQ (2005); Kenneth M. Pollock / Iraq Policy Working Group, A Switch in Time - a New Strategy for America in Iraq, (2006). Pollock is the most optimistic of the group, despite the devastating record he attests the policy so far. The policy prescriptions he advocates, however, remain less than convincing, ranging from the introduction of food stamps (p. xvi) to raising overall troop numbers to 450,000 (p. x).

11 See inter alia Erika de Wet, The Illegality of the Use of Force Against Iraq Subsequent to the Adoption of Resolution 687 (1991), 3 HUMANITÄRES VÖLKERRECHT 125-32 (2003); Lori Fisler Damrosch / Bernard H. Oxman, Editor's Introduction, 97 AMERICAN JOURNAL OF INTERNATIONAL LAW 556 (2003); Lori Fisler Damrosch / Bernard H. Oxman / et al., Agora: Future Implications of the Iraq Conflict, 97 AMERICAN JOURNAL OF INTERNATIONAL LAW 553-656 (2003); Carsten Stahn, Enforcement of the Collective Will After Iraq, 97 AMERICAN JOURNAL OF INTERNATIONAL LAW 804-23 (2003); John C. Yoo, International Law and the War in Iraq, 97 AMERICAN JOURNAL OF INTERNATIONAL LAW 563 (2003); Alex J. Bellamy, International Law and the War With Iraq, 4 MELBOURNE JOURNAL OF INTERNATIONAL LAW 497-520 (2003).

12 Declared by President Bush in a speech aboard the warship USS Abraham Lincoln. The speech has since proved a source of considerable embarrassment to the president, due to its staged nature and the realisation that given the violence in Iraq its major claims were premature. See inter alia Michael Elliott, So What Went Wrong?, TIME 2003, at 14.

The president deliberately did not declare the end of the war, arguably to avoid legal responsibilities related to prisoners of war and war criminals, see M. Hmond, The Use of Force Against Iraq: Occupation and Security Council Resolution 1483, 36 CORNELL INTERNATIONAL LAW JOURNAL 443 (2004). This line of argument has been criticised by Rüdiger Wolfrum, Iraq: From Belligerent Occupation to Iraqi Exercise of Sovereignty: Foreign Power Versus International Community Interference, 9 MAX PLANCK YEARBOOK OF UNITED NATIONS LAW (2005), 2.

${ }^{13}$ Gary D. Brown, Proportionality and Just War, 2 JOURNAL OF MILITARY ETHICS 171 - 185 (2003); CHRISTOPHER ANGLIM, THE IRAQ WAR (2003) - A DOCUMENTARY LEGAL HISTORY (2004); Ronli Sifris, Operation Iraqi Freedom - United States $v$ Iraq - the Legality of the War, 4 MELBOURNE JOURNAL OF INTERNATIONAL LAW 521-60 (2003). 
It has been argued that the static nature of occupation law places an undue emphasis on preserving the socio-political status quo of an occupied territory. Given the increasing acceptance within the international community of the applicability of certain universal standards of human rights and good governance, ${ }^{14}$ and given further the belief in a causal link between internal repressiveness and external aggression it has been held that the traditional concept of state sovereignty needs to be modified to account for these universal values..$^{15}$

The traditional notion of state sovereignty is reflected in what appears to be a fairly straight-forward legal rule of occupation law protecting the institutions, legal and social system of the occupied territory from alterations by the occupant. Article 43 of the Hague Regulations states:

The authority of the legitimate power having in fact passed to the hands of the occupant, the latter shall take all measures in his power to restore and ensure, as far as possible, public order and safety, while respecting, unless absolutely prevented, the laws in force in the country. ${ }^{16}$

The provision contains three substantive elements: the occupation regime is based on factual control, it establishes the right as well as the duty of the occupier to provide security, and, importantly, stresses the temporary nature of the occupation regime by protecting the continued existence of the occupied state. Pictet is quite categorical in this respect:

the occupying power [is] to be considered as merely being a de facto administrator. This provision of the Hague Regulations (Art. 43 ) is not only applicable to the inhabitants of the occupied territory; it also protects the separate existence of the state, its institutions and its laws. ${ }^{17}$

\footnotetext{
${ }^{14}$ Michael W. Reisman, Sovereignty and Human Rights in Contemporary International Law, 84 AMERICAN JOURNAL OF INTERNATIONAL LAW 866 et seq. (1990); GREGORY H. FOX / BRAD R. ROTH (EDS.), DEMOCRATIC GOVERNANCE AND INTERNATIONAL LAW (2000); Rudolf Dolzer, Good Governance: Neues Transnationales Leitbild der Staatlichkeit?, 64 ZEITSCHRIFT FÜR AUSLÄNDISCHES ÖFFENTLICHES RECHT UND VÖLKERRECHT 535-46 (2004).

15 Juliane Kokott, Souveräne Gleichheit und Demokratie im Völkerrecht, 64 ZEITSCHRIFT FÜR AUSLÄNDISCHES ÖFFENTLICHES RECHT UND VÖLKERRECHT 517-33 (2004).

${ }^{16}$ Regulations Respecting the Laws and Customs of War on Land, annexed to Convention respecting the Laws and Customs of War on Land, 18 October 1907, 36 Stat. 2277, 2 AJIL Supp. 90 (1908).

${ }^{17}$ JEAN PICTET (ED.), COMMENTARY ON GENEVA CONVENTION IV OF 1949 (1958), 273.
} 
It has now been argued that irrespective of the legality or legitimacy of the armed conflict that gives rise to the occupation regime, the transformation of an oppressive and aggressive governmental system is in the interest of the international community and possibly necessary for the maintenance or restoration of international peace. To demand therefore that an occupier should respect the legal and socio-political system put in place by a tyrannical regime seems counterintuitive. Thus even writers who have questioned the ius ad bellum have maintained that "[g]iven the technical and, in particular, political changes that have occurred in modern warfare, international humanitiarian law can no longer be considered comprehensive." 18

The requirement by the international community that international humanitarian law, including the law of occupation will be strictly respected ${ }^{19}$ has in principle been recognised by the United States and the United Kingdom as the main coalition powers..$^{20}$ Regarding the introduction of far-reaching political changes in Iraq, however, there has been an element of tension between the above stated requirement to respect the laws and institutions in place, and the perceived necessity to fundamentally transform Iraqi society. To defuse this tension it has been argued that international humanitarian law needs to be developed to permit such necessary transformative processes by the occupier.

This paper argues that irrespective of the unquestionable desirability, even necessity to introduce democratic and liberal reforms into a society such as the Iraqi one, an occupation regime cannot be considered the adequate tool. The law of occupation is primarily a negative boundary marker to protect the occupied population from abuse. Calls for a revision of the law of occupation assume a commonality of interest between occupier and the occupied population that is unlikely to find widespread acceptance in the target population. Whatever the shortcomings of the current law of occupation, claiming its obsolescence conveniently disregards the fact that a clear and evidently usable mechanism exists in the instrument of a robust Security Council mandate which could easily provide the legal basis for the kind of societal and state transformation deemed necessary.

${ }^{18}$ Wolfrum, Iraq: From Belligerent Occupation to Iraqi Exercise of Sovereignty, 9 MAX PLANCK YEARBOOK OF UNITED NATIONS LAW (2005), 5.

${ }^{19}$ Recognised primarily in S/RES/1483 (2003) of 22 May 2003, preamb. para. 13, op. para. 5.

20 Using somewhat guarded language in the Letters Dated 8 May 2003 from the Permanent Representatives of the United Kingdom of Great Britain and Northern Ireland and the United States of America to the United Nations Addressed to the President of the Security Council, UN Doc. S/2003/538. 
Scheffer for instance agrees that current humanitarian law is inadequate to address the needs of a society in political, judicial, and economic collapse which "requires far more latitude for transformational development than would be anticipated under these instruments [the Hague Regulations and Geneva Conventions]."21 But he is quick to point out that an evidently usable alternative mechanism already exists in the form of Security Council authorisation: "the intended political transformational process in Iraq "requires strained interpretations of occupation law to suit modern requirements. Such unique circumstances are far better addressed by a tailored nation-building mandate of the Security Council." 22

That such a mandate could not be obtained reflects the lack of consensus about how such a transformation could or should have been achieved. The subsequent failure of the process put in motion by the occupation ${ }^{23}$ forces attests to the importance of legitimacy and multilateral involvement, something that can only be sustained through a clear multilateral mandate. More importantly, a successful socio-political transformation rests on the acceptance by the target population of its means and direction. The status quo limitations imposed by the law of occupation should thus not be interpreted as safeguarding anachronistic institutions but as protecting the right of the population to determine its own socio-political structure. The failure of the US-led political process also hints at the inherent limits of effecting such farreaching transformative processes by occupational fiat. These inherent limits are mirrored in the limitations imposed by humanitarian law, pointing to a certain humility about the possibilities of military power. It is this respect that we argue that despite its evident shortcomings international humanitarian law might actually be far more pertinent than the repeated calls for its development suggest.

\section{B. Reasons for Failure}

Three interrelated aspects have severely hamstrung the reconstruction efforts in Iraq from the beginning: the failure to provide security in the aftermath of the conflict, the absence of a clear political strategy, and the lack of legitimacy of the occupation. Overall, the situation provides, in the words of former National Security Advisor Zbigniew Brzezinski, a "striking contrast" between the situation

\footnotetext{
${ }^{21}$ David J. Scheffer, Beyond Occupation Law, 97 AMERICAN JOURNAL OF INTERNATIONAL LAW (2003), 849.

${ }^{22}$ Scheffer, Beyond Occupation Law, 97 AMERICAN JOURNAL OF INTERNATIONAL LAW (2003), 843.

${ }_{23}$ Charles Tripp, The United States and State-Building in Iraq, 30 REVIEW OF INTERNATIONAL STUDIES 545-58 (2004).
} 
in Afghanistan as compared to Iraq. ${ }^{24}$ It provides in many respects a cautionary tale about the inherent limits of military power: "President Bush's characterization of the invasion of Iraq as a "catastrophic success" depicts a unique reality: a relative ease in invading a country but difficulty in governing it." 25

With few dissenting voices, ${ }^{26}$ most analyses stress the glaring lack of preparation and advance planning, coupled with a steadfast refusal to accept realities on the ground to explain the failure of such well-intentioned policy. ${ }^{27} \mathrm{~A}$ very large number of competent examinations of the strategic and tactical mistakes have been undertaken, coming to quite different conclusions about the proper course of action to be followed now. ${ }^{28}$ Most, however, seem to agree about the "paucity of good options now before the United States." 29

${ }^{24}$ Quoted by Karl Inderfurth in Thomas P. Lauth et al., Building the Institutions of the Nation, 33 GEORGIA JOURNAL OF INTERNATIONAL AND COMPARATIVE LAW (2004), 186; Daniel Byman et al., Iraq, Afghanistan and the War on "Terror", 12 MIDDLE EAST POLICY 1-24 (2005); ANTHONY H. CORDESMAN, THE WAR AFTER THE WAR: STRATEGIC LESSONS OF IRAQ AND AFGHANISTAN (2004); Anthony H. Cordesman, American Strategic, Tactical, and Other Mistakes in Iraq: A Litany of Errors, 2006.

${ }^{25}$ Abbas J. Ali / Philip M. Nufrio, Post War Iraq: Understanding and Shaping the Forces of Positive Changes, 10 PUBLIC ADMINISTRATION AND MANAGEMENT (2005), 31. Ali and Nufrio continue with a stark comparison: "Indeed, the U.S. invasion of Iraq in 2003 is similar in many aspects to the Mongol invasion of Iraq in 1258. While the Mongols were effective in ending the Abbasids regime, they had to forcefully suppress the Iraqis into submission. Years later, the Mongols exited Iraq but left it in ruins."

${ }^{26}$ Rubin of the American Enterprise Institute denounces most critics of having no first-hand experience of Iraq and concludes: "The future of Iraq is anything but bleak." Michael Rubin, The Future of Iraq: Democracy, Civil War, Or Chaos?, 9 MIDDLE EAST REVIEW OF INTERNATIONAL AFFAIRS, no pagination (2005); Charles Krauthammer, A Sensible Iraqi Constitution, WASHINGTON POST, at A29.

${ }^{27}$ Gerard Toal, A Conversation With Peter Galbraith About Iraq and State Building, GEOPOLITICS (2005), 171; Louis J. Cantori et al., Evaluating the Bush Menu for Change in the Middle East, Roundtable of the Conference Group on the Middle East At the American Political Science Association Annual Meeting, Chicago, September 5, 2004, 12 MIDDLE EAST POLICY 97-121 (2005).

${ }^{28}$ Former ambassador Galbraith and the head of the Council of Foreign Relations Gelb argue for a partition of the country into sustainable entities along ethnic lines; former Secretary of Defence Laird argues for an "Iraqisation" of security forces along the policy attempted in Vietnam allowing for a gradual withdrawal of US forces; RAND scholar Dobbins agrees with the need to place the main burden of security on moderate Iraqis, but believes that through its lack of legitimacy and credibility the US "has already lost the war" forcing Iraqis to look for support elsewhere. He thus argues for a regional initiative with strong Iranian involvement. Stanford political scientist Larry Diamond agrees that the growing legitimacy and credibility gap, resulting primarily from totally inadequate security provisions, i.e. troop numbers, severely hampered reconstruction efforts, stressing the need to build state and security structures because "a country must first have a state before it can become a democracy." Military expert Krepinevich argues for staying the course but that a change in military tactics is required, based around the principles of counterinsurgency warfare. He argues that a so-called "oil-spot strategy" should focus on providing security in limited areas that would gradually spread rather than hunting down insurgent. His approach has since been adopted by the US Army. Pollock's fairly positive (but by now somewhat 


\section{Lack of Security}

No one seriously doubted the outcome of the war, although there had been some surprise about the relative ease with which Coalition forces vanquished Iraqi formal units. ${ }^{30}$ The strategy seemed a resounding validation of the new military doctrine expounded by Secretary of Defence Rumsfeld against more cautious professional officers following the hitherto accepted military doctrine.

This so-called Weinberger-Powell doctrine stipulated the application of overwhelming force as offering the greatest possibility of success while minimising casualties on both sides. ${ }^{31}$ Limited force, to be gradually enlarged as necessity grows, only invites the enemy to a test of wills that will draw out the conflict. This applies to both the period of actual combat as well as the post-conflict phase: "There appears to be an inverse correlation between the size of the stabilization force and the level of risk. The higher the proportion of stabilizing troops, the lower the number of casualties suffered and inflicted." 32

To reduce the political and economic costs of such massive troop deployments the doctrine was subsequently modified to maximise the utility of unique American technical assets, especially its unassailable advantage in the so-called Revolution in

dated) assessment likewise questions whether "quick Iraqification" of security provision can be achieved. In a recent co-authored piece he makes a series of recommendations which remain unconvincing. Despite rhetoric to the contrary, the they fall far short of a convincing counter-strategy and one is left with the distinct realisation that the point of no return has basically been reached for US efforts and failure can no longer be avoided.

James Dobbins, Iraq: Winning the Unwinnable War, FOREIGN AFFAIRS no pagination (2005); Peter Galbraith, How to Get Out of Iraq, 51 THE NEW YORK REVIEW OF BOOKS no pagination (2004); Leslie H. Gelb, The Three State Solution, NEW YORK TIMES, at A27; Melvin R. Laird, Iraq: Learning the Lessons of Vietnam, FOREIGN AFFAIRS no pagination (2005); Larry Diamond, What Went Wrong in Iraq?, FOREIGN AFFAIRS no pagination (2004); Larry Jay Diamond, Lessons From Iraq, 16 JOURNAL OF DEMOCRACY 9-23 (2005); Rubin, The Future of Iraq: Democracy, Civil War, Or Chaos?, 9 MIDDLE EAST REVIEW OF INTERNATIONAL AFFAIRS no pagination (2005); Andrew F. Jr. Krepinevich, How to Win in Iraq, FOREIGN AFFAIRS no pagination (2005); Kenneth M. Pollock, After Saddam: Assessing the Reconstruction of Iraq, (2004); Pollock / Iraq Policy Working Group, A Switch in Time - a New Strategy for America in Iraq, (2006).

${ }^{29}$ Dobbins, Iraq: Winning the Unwinnable War, FOREIGN AFFAIRS no pagination (2005).

${ }^{30}$ For military details see ANTHONY H. CORDESMAN, THE IRAQ WAR: STRATEGY, TACTICS AND MILITARY LESSONS (2003).

31 John L. Hirsch / Robert B. Oakley, Somalia and Operation Restore Hope, (1995), 77.

32 JAMES DOBBINS et al., AMERICA'S ROLE IN NATION-BUILDING: FROM GERMANY TO IRAQ (2003), 198. 
Military Affairs (RMA) to reduce manpower requirements. ${ }^{33}$ With reference to American pre-eminence in RMA, it was argued that victory could be achieved with far fewer troop numbers than hitherto assumed. Against the objections of the professional officer corps, ${ }^{34}$ the strategy used against Iraq was heavily based on mobility and firepower, but deploying substantially fewer soldiers than initially thought necessary. ${ }^{35}$ Battlefield developments seemed to solidly vindicate the new strategy.

The occupation, however, exposed the shortcomings of this approach. Although the complete breakdown of social order was predictable ${ }^{36}$ and had in fact been predicted, ${ }^{37}$ no adequate mechanisms had been put in place. Commenting on the sacking of the national museum and other sites, Anne Joyce asks the prescient question: "Will the United States do a better job at nation building than at arthistorical preservation? The omens are not encouraging. President Bush has ended the war by declaring victory, but that is beyond his control. Wars only end when the defeated accept defeat." 38

One lesson derived from the peacekeeping missions of the 1990s has been that insurgents, whether motivated for political or essentially criminal reasons, will test

${ }^{33}$ RMA refers to the combined use and networked effect of high-altitude bombing with precision ammunition, wide-spread use of stealth technology, small, but highly mobile units drawn from different services but acting with very high degrees of coordination using real-time communication and positioning technology. See inter alia John J. Mearsheimer, Hans Morgenthau Und Der Irakkrieg, 59 MERKUR (2005), 838; JOHN P. WHITE / ZALMAY KHALILZAD (EDS.), THE CHANGING ROLE OF INFORMATION IN WARFARE (1999).

${ }^{34}$ General Shinseki's retirement was announced a year early, severely compromising his professional standing. Diamond, What Went Wrong in Iraq?, FOREIGN AFFAIRS no pagination (2004).

${ }^{35}$ During the 2003 campaign roughly 264,000 Coalition soldiers (214,000 Americans, 45,000 British, 2,000 Australians and 2,400 Polish) participated, while in the 1991 campaign 660,000 Coalition troops were deployed, with no occupation duties envisaged. See Wikipedia, 2003 Invasion of Iraq, 2006, available at: http://en.wikipedia.org/wiki/2003_Invasion_of_Iraq; Wikipedia, Gulf War, 2006, available at: http://en.wikipedia.org/wiki/Desert_Storm. For additional details see CORDESMAN, THE IRAQ WAR: STRATEGY, TACTICS AND MILITARY LESSONS (2003).

The highly optimistic approach taken by the Pentagon is evidenced in the initial plan to draw troop numbers in Iraq until Summer 2003 down to 25,000 troops. See GEORGE PACKER, THE ASSASSINS' GATE: AMERICA IN IRAQ (2005).

${ }^{36}$ Massive looting had already occurred in the aftermath of the 1991 Iraq war.

37 See inter alia Anthony H. Cordesman, Planning for a Self-Inflicted Wound: US Policy to Reshape a PostSaddam Iraq, 2002. See also the comment by the former British arts minister, Mark Fisher, Tomb Raiders, THE GUARDIAN, 21 January 2006.

${ }^{38}$ Anne Joyce, Editor's Note, 10 MIDDLE EAST POLICY (2003), iv, emphasis added. 
the resolve of the outside force trying to maintain control. Academic and official consensus thus gradually shifted from consensual peacekeeping to muscular peaceenforcing. ${ }^{39}$ Oakley and Hirsch examined the fiasco in Somalia and came to the conclusion that the basic tenets of normal US war-fighting doctrine also applied in post-conflict situations: convincing the (potential) opponent to accept defeat through the provision (though not necessary application) of overwhelming force. ${ }^{40}$

That Iraq was an occupation and not a mandated peace-enforcing mission is not of much import in this respect. What matters is that the occupation force very quickly lost the initiative, credibility, and, ultimately, legitimacy by deploying too few and the wrong kind of troops to maintain the security which is a sine qua non of the subsequent political reconstruction process. ${ }^{41}$ Dobbins gave at the time some interesting statistical comparisons between the requisite numbers troop and civilian police numbers required for successful pacification. ${ }^{42}$ These numbers are now widely considered to have been accurate, ${ }^{43}$ but faced with the real prospect of civil war, ${ }^{44}$ the Coalition is actually drawing down its numbers in preparation for a full withdrawal. ${ }^{45}$

39 Rosalynne Higgins, The New United Nations and Former Yugoslavia,; Lakhdar Brahimi / et al., Report of the Panel on United Nations Peace Operations ("the Brahimi Report"), UN Doc a/55/305-S/2000/809, (2000).

${ }^{40}$ Hirsch / Oakley, Somalia and Operation Restore Hope, (1995), 77; Adam Roberts, Humanitarian Action in War, Adelphi Paper 305, ADELPHI PAPERS (1996); Barry R. Posen, Military Responses to Refugee Disasters, 21 INTERNATIONAL SECURITY 72-111 (1996); CHARLES DOBBIE, A CONCEPT FOR POST-COLD WAR PEACEKEEPING (1994).

${ }^{41}$ Diamond, What Went Wrong in Iraq?, FOREIGN AFFAIRS no pagination (2004).

${ }^{42}$ Based on the levels deployed in Kosovo approximately 526,000 foreign troops and 53,000 international civilian police would have been required in Iraq. See James Dobbins, America's Role in Nation-Building: From Germany to Iraq, 2003, Heinrich Böll Stiftung, available at:

www.boell.de/downloads/demokratiefoerderung/dobbins_americas_role.pdf, 16-17.

${ }^{43}$ Pollock is quoting 440,000 as "the baseline figure for what will be required ultimately to stabilize Iraq." Pollock / Iraq Policy Working Group, A Switch in Time - a New Strategy for America in Iraq, (2006), 25.

${ }^{44}$ International Crisis Group, The Next Iraqi War? Sectarianism and Civil Conflict, MIDDLE EAST BRIEFING NO. 52 (2006); Anthony H. Cordesman, The Iraqi Insurgency and the Risk of Civil War: Who Are the Players?, 2006; Anthony H. Cordesman / Eric M. Brewer / Sara Bjerg Moller, Iraq's Evolving Insurgency and the Risk of Civil War, 2006.

${ }^{45}$ From December 2005 until March 2006 US troop numbers had been reduced from 160,000 to 132,000., Rumsfeld Will US Soldaten Aus Bürgerkrieg Im Irak Heraushalten, DER SPIEGEL - ONLINE EDITION, 10 March 2006. 


\section{Lack of Political Strategy}

A related problem is the lack of a clear strategy for the socio-political reconstruction of the country. The situation again contrasts rather unfavourably with Afghanistan, where an ambitious but reasonable timetable was agreed in advance among all the major factions who were given sufficient stakes in the process to stay engaged and where spoilers were dealt with effectively through cooptation or intimidation. In Iraq, however, even the Economist, an early and consistent supporter of the war, ${ }^{46}$ had to observe that: "Over the past year, Paul Bremer, Iraq's American administrator, has changed his plans so many times that Iraqis themselves, let alone spectators from afar, can be forgiven for being confused about what the Americans are currently proposing. This lack of clarity is one of the many failures of the occupation so far." 47

The level of unpreparedness, particularly compared to earlier, successful nationbuilding exercises ${ }^{48}$ is certainly surprising and has undoubtedly greatly put at risk the nation-building and democratisation efforts. But as Katz aptly points out, "our ineptness with regard to these practical, local and immediate issues is much less significant than our conceptual unpreparedness, a shortage of both analysis and imagination about the possibility of different, equally legitimate shapes democratic constitutionalism might take in these places." 49 This absence of comparative thinking, linked with the lack of knowledge about the country and its inhabitants

\footnotetext{
${ }^{46}$ An interesting change of position in this regard is detectable in Pollock, who reversed his earlier 1999 assessment that an invasion would be "a terrible mistake" based either on wishful thinking or cynical politics, by arguing the case of invasion in 2002. He has since regretted that latter stance, and come out strongly against the further use of violence to achieve political change in the region, with regard to Iraq he argues for staying the course against a premature withdrawal of troops. See Daniel Byman / Kenneth M. Pollock / Gideon Rose, The Rollback Fantasy, FOREIGN AFFAIRS (1999); KENNETH M. POLLOCK, THREATENING STORM: THE CASE FOR INVADING IRAQ (2002); KENNETH M. POLLOCK, THE PERSIAN PUZZLE: THE CONFLICT BETWEEN IRAN AND AMERICA (2004); Deborah Solomon, Questions for Kenneth Pollock, THE NEW YORK TIMES MAGAZINE; Pollock / Iraq Policy Working Group, A Switch in Time - a New Strategy for America in Iraq, (2006).

47 Anonymous, The Challenge in Iraq, THE ECONOMIST 9 (2004).

${ }^{48}$ An element often under-emphasised in the once fashionable comparisons between Germany/Japan to Afghanistan/Iraq, see Stanley N. Katz, Gun Barrel Democracy? Democratic Constitutionalism Following Military Occupation: Reflections on the U.S. Experience in Japan, Germany, Afghanistan and Iraq, Princeton Law and Public Affairs Working Paper No. 04-010, PRINCETON LAW AND PUBLIC AFFAIRS WORKING PAPER SERIES SPRING SEMESTER (2004), 1; DOBBINS et al., AMERICA'S ROLE IN NATIONBUILDING: FROM GERMANY TO IRAQ (2003).

${ }^{49}$ Katz, Gun Barrel Democracy? Democratic Constitutionalism Following Military Occupation, PRINCETON LAW AND PUBLIC AFFAIRS WORKING PAPER SERIES SPRING SEMESTER (2004), 1-2, emphasis in the original.
} 
severely constrained the Coalition's ability to put into motion a political process driven by and "bought into" by local actors. The almost complete lack of any international, i.e. non-American experts with relevant post-conflict experience, as well as the disproportionate reliance on Iraqi exiles of questionable reputation and with virtually no domestic following, further reduced the likelihood of finding suitable solutions acceptable to the population.

\section{Lack of Legitimacy}

The fact that by now "Iraq has gone from being a rogue state to being an ailing, if not failing one" 50 poses important questions about the importance of legitimacy, institutional design, and popular participation. It also tells us much about the limits of external imposition.

In 1949 Carl Schmitt ranted against the perceived indignity to which Germany had purportedly been subjected by writing: "In medieval theory, the just war meant that the victor had the right to enslave the subjects of his opponent and to seize his land; today, with more highly organized forms of mass domination it means above all: determining the constitution and regime of the defeated." 51 Perhaps it would offer some consolation to him to observe the very real difficulties the Coalition has had and continues to have to impose any type of functioning government, let alone one of its own volition, thereby attesting to the inherent limits of power projection.

As the difficulties of the Coalition in Iraq attest to - particularly if contrasted to the relative success of the Afghanistan venture - societal transformation cannot be achieved without a modicum of domestic legitimacy which rests on and is reflected in international legitimacy. The best medium to obtain such legitimacy is through the established channels of the United Nations, which furthermore provide the legal instruments in the form of robust Security Council mandates to effect such wholesale transformational processes. In the absence of such international consensus and mandate, the strictures of the law of occupation serve precisely the same end as at the time of their conception, namely to prevent the abuse of power:

50 Phebe Marr, Occupational Hazards, FOREIGN AFFAIRS no pagination (2005).

51 CARL SCHMITT, GLOSSARIUM: AUFZEICHNUNGEN DER JAHRE 1947-1951 (1991), 269.; Stirk correctly terms this a "dubious analogy that nevertheless says a great deal about his perception of the experience." Peter Stirk, Carl Schmitt, the Law of Occupation, and the Iraq War, 11 CONSTELLATIONS (2004), 527. 
[It is] a false premise that Article 43 of the Hague Convention conferred upon the occupying power a positive right to legislate; ... it is inaccurate to say that by virtue of the Convention the occupant has been given any portion of legislative authority; ... it appears from the text of the Convention itself and from the preliminary work that all that was intended ... was to restrict the abuse of force by the occupant and not to give him or recognize him as possessing any authority in the sphere of law. 52

The shortcomings of the Coalition performance with regard to maintenance of public order and security are compounded by the perception of financial impropriety ${ }^{53}$ during the occupation period resulting not only in the loss of

52 The Belgian Court of Appeal held likewise in the case of Mathot v. Longué relating to the First World War, 19 February 1921, quoted in Conor McCarthy, The Paradox of the International Law of Military Occupation: Sovereignty and the Reformation of Iraq, 10 JOURNAL OF CONFLICT AND SECURITY LAW (2005), 47, emphasis added.

${ }^{53}$ When the CPA assumed its work, there were about 6 billion US\$ left over from the UN Oil for Food Programme plus sequestered and frozen accounts, as well as at least 10 billion US\$ from resumed Iraqi oil exports. S/RES/1483 of 22 May 2003, para. 12 "takes note" of the establishment of the Development Fund for Iraq (DFI) and mandates in para. 16 (d) that earlier accounts established pursuant to Resolution 986 (1995), paras. 8 (a) and 8 (b) are to be consolidated in it.

While para. 13 "notes" the fact that this Fund will be disbursed under the direction of the CPA, Resolution 1483, para. 14 stresses that the Fund "shall be used in a transparent manner" for the benefit of the Iraqi people and "in consultation with the Iraqi interim administration" (para. 13). For this purpose the CPA set up the 'Program Review Board' to award respective contracts and to administer the DFI on behalf of the Iraqi people, as well as the Iraq Relief and Reconstruction Fund provided by Congress (an additional 18.4 billion US\$) on behalf of the American people.

Resolution 1483, para. 12 required the establishment of an International Advisory and Monitoring Board $(I A M B)$ to be composed of senior members of international developing finance institutions to oversee how the DFI was spent. In consultation with the CPA it appointed the Bahrain office of the international accounting firm KPMG to audit these expenses. The reports of both KPMG and the IAMB lamented the "resistance encountered from CPA staff" and stated "financial irregularities." Furthermore, despite its repeated requests and assurances by the CPA to the IAMB that meters would be installed/repaired, this was never done during the tenure of the CPA, suggesting significant under-reporting of oil exports; the unaccounted revenue is estimated to be between 2-4 billion US\$. 8.8 billion US\$ passing through Iraq ministries during the CPA's tenure remain unaccounted for. 3 billion US\$ in new contracts were handed out in the last weeks of the CPA, to be managed by the US embassy. See International Advisory and Monitoring Board, Development Fund for Iraq Audit, 2004, IAMB, available at: www.iamb.info/dfiaudit.htm; International Advisory and Monitoring Board, Appendix to the audit of the Development Fund for Iraq - Matters noted involving internal controls and other operations issues during the audit of the Fund for the period up to 31 December 2003, 2004, IAMB; International Advisory and Monitoring Board, KPMG's Audit Notes, 2004, IAMB, available at: www.iamb.info/auditrep/r052203a.pdf.

Further evidence has been provided by the CPA's own Inspector General's Office (CPAIG), now renamed Special Inspector General for Iraq Reconstruction (Sigir), particularly concerning the above mentioned new contracts. "we identified deficiencies in the control of cash ... of such magnitude as to require prompt attention. Those deficiencies were so significant the we were precluded from 
substantial American and Iraqi resources, but also in loss of essential services not being provided. The troubling legal void surrounding Iraqi nationals in occupation captivity, ${ }^{54}$ and the perceived lack of accountability and legal redress for transgressions by occupation forces ${ }^{55}$ and their private contractors ${ }^{56}$ have further

accomplishing our stated objectives."). Quoted in Ed Harriman, So, Mr Bremer, Where Did All the Money Go?, THE GUARDIAN/LONDON REVIEW OF BOOKS, 9 July 2006.

Part of this wastage has been defended one the one hand by the need to kick-start the economy ("pour in billions of dollars. That is the only way to do it. It does not matter where it goes; we just need to get the economy moving. We could drop it from helicopters and it would probably do about as much good as most USAID programs", Howard Wiarda in Lauth et al., Building the Institutions of the Nation, 33 GEORGIA JOURNAL OF INTERNATIONAL AND COMPARATIVE LAW (2004), 193.) The other justification has been to purchase security by paying off informants and warlords, a strategy used to good effect already in Afghanistan, see inter alia Jonathan Goodhand, From War Economy to Peace Economy? Reconstruction and State Building in Afghanistan, 58 JOURNAL OF INTERNATIONAL AFFAIRS 155 (2004).

These are Iraqi funds that are being wasted and embezzled, not American ones. It has been criticised that during its operation, the CPA spent up to 20 billion US\$ of Iraqi money through the DFI, while only about 400 million (!) US\$ out of 18.4 billion US\$ provided by Congress. This has been partly explained by the desire to reduce the burden on the American treasury, partly by avoiding oversight by the Congressional Accounting Office. See --, --, Rules and Cash Flew Out of the Window, LA TIMES; Ariana Eunjung Cha, In Iraq, the Job Opportunity of a Lifetime: Managing a \$13 Billion Budget With No Experience, WASHINGTON POST, at A01; Wikipedia, Coalition Provisional Authority, 2006, available at: http://en.wikipedia.org/wiki/Coalition_Provisional_Authority.

Whether these practices are in line with the usufructuary requirements of the law of occupation can be doubted. For a detailed discussion see Ed Harriman, So, Mr Bremer, Where Did All the Money Go?, THE GUARDIAN/LONDON REVIEW OF BOOKS.; see also Eyal Benvenisti, Water Conflicts During the Occupation of Iraq, 97 AMERICAN JOURNAL OF INTERNATIONAL LAW (2003), 869; Antonio Cassese, Powers and Duties of an Occupant in Relation to Land and Natural Resources, INTERNATIONAL LAW AND THE ADMINISTRATION OF OCCUPIED TERRITORIES: TWO DECADES OF ISRAELI OCCUPATION OF THE WEST BANK AND GAZA STRIP (Emma Playfair ed., 1992); U.S. Department of State, Memorandum of Law on Israel's Right to Develop New Oil Fields in Sinai and the Gulf of Suez, 16 ILM (1977), 743.; ("property can be taken only for the purposes of the occupation itself"); especially pertinent: ERNST H. FEILCHENFELD, THE INTERNATIONAL ECONOMIC LAW OF BELLIGERENT OCCUPATION (1942), 55.; ("While the belligerent occupant may lease or utilize public lands or buildings, sell the crops, cut and sell timber, and work the mines, a lease or contract should not extent beyond the conclusion of the war." Emphasis added.)

${ }^{54}$ Human Rights Watch, Leadership Failure: Firsthand Accounts of Torture Or Iraqi Detainees By the U.S. Army's 82Nd Airborne Division, VOLUME 17, NO. 3(G) (2005); Amnesty International, Beyond Abu Ghraib: Dentention and Torture in Iraq, Mde 14/001/2006, (2006).

${ }^{55}$ For a fairly sympathetic discussion stressing the "dedication and professionalism of those involved at the CPA and other entities that worked so hard during the transition from dictatorial rule to a new government based on democratic principles" see J. Stephen Shi, The Legal Status of Foreign Military and Civilian Personnel Following the Transfer of Power to the Iraqi Interim Government, 33 GEORGIA JOURNAL OF INTERNATIONAL AND COMPARATIVE LAW 245-60 (2004). 
eroded popular trust in the occupation regime. Particularly the issue of immunity ${ }^{57}$ extended summarily and prospectively 58 to virtually any non-Iraqi entity or individual ${ }^{59}$ has proved to be controversial, both domestically and internationally. ${ }^{60}$ While it might appear to an American observer that the measures chosen are "appropriate and reasonable," 61 to the average Iraqi, particularly within the Shi' $i$ community, the similarity to the founding act of the Iranian revolution ${ }^{62}$ won't be lost.

\section{The Purpose of the Law of Occupation}

In order to minimise the impact of violence in war in the widest possible arenas, international humanitarian law deliberately takes no position on the legitimacy of the conflict as such. The law of occupation stipulates a simple factual test, 63 i.e. any territory "actually placed under the authority of the hostile army," is deemed to be

56 On this aspect in general see Peter Warren Singer, War, Profits, and the Vacuum of Law: Privatized Military Firms and International Law, 42 COLUMBIA JOURNAL OF TRANSNATIONAL LAW 521 et seq. (2004); Clifford J. Rosky, Force, Inc.: The Privatization of Punishment, Policing, and Military Force in Liberal States, 36 CONNECTICUT LAW REVIEW 879 et seq. (2004).

${ }^{57}$ CPA/ORD/17 June 2004/17 (Status of the Coalition Provisional Authority, MNF-Iraq, Certain Missions and Personnel in Iraq) (revising and extending the earlier Order No. 17)

${ }^{58}$ CPA/ORD/17 June 2004/17, though issued by the CPA in the last days of its operation was aimed at regulating the situation under the authority of the Iraqi Interim Government, i.e. after the handover of sovereignty.

59 CPA/ORD/17 June 2004/17 §1; this includes all official military and diplomatic personnel and also anyone working under any type of "contract" as defined in \$1(13).

${ }^{60}$ Amnesty International, Iraq: Memorandum on Concerns Relating to the Rule of Law, Mde 14/157/2003, (2003); Amnesty International, Iraq: Memorandum on Concerns Related to Legislation Introduced By the Coalition Provisional Authority, Mde/14/176/2003, (2003).

61 Shi, The Legal Status of Foreign Military and Civilian Personnel, 33 GEORGIA JOURNAL OF INTERNATIONAL AND COMPARATIVE LAW (2004), 260.

62 The conclusion of a treaty granting immunity to American military personnel in Iran in 1963 led to Ruhollah Khomeini breaking ranks with the quietist ulema to openly challenge the government. This led to his incarceration, in the course of which he was promoted to the rank of Ayatollah, presumably to save him from execution, and his subsequent banishment to Iraq, where he remained until 1977 and from where he organised the successful revolution. See ERVAND ABRAHAMIAN, KHOMEINISM: ESSAYS ON THE ISLAMIC REPUBLIC (1993); BAQER MOIN, KHOMEINI: THE LIFE OF THE AYATOLLAH (2000); CHIBLI MALLAT, THE RENEWAL OF ISLAMIC LAW : MUHAMMAD BAQER AS-SADR, NAJAF, AND THE SHI'I INTERNATIONAL (1993).

63 McCarthy, The Paradox of the International Law of Military Occupation, 10 JOURNAL OF CONFLICT AND SECURITY LAW (2005), 45. 
occupied for the purpose of the applicability of the rules. ${ }^{64}$ This factual test does neither depend on the recognition of the occupation by the occupier nor is it contingent on the armed conflict that gave rise to the occupation having been in conformity with international law. ${ }^{65}$

The law of occupation provides the legal framework for the temporary exercise of governmental authority by the occupier, trying to strike a balance between his security needs and the interests of the population. 66 There has been much commentary about the increasing inadequacy of the basic premise underlying the law of occupation, namely that the exercise of temporary authority to which the occupier is entitled does not grant him a mandate to introduce wholesale changes in the legal, political, and economic structure of the territory in question. ${ }^{67}$

Calls for a revision of the rules and references to the alleged inadequacy of the law of occupation seem to start from the assumption of a certain commonality of interests, sometimes likened to some form of trusteeship. ${ }^{68}$ But it is by no means self-evident that such a commonality of interests actually exists. In most instances

${ }^{64}$ Regulations Respecting the Laws and Customs of War on Land, annexed to Convention respecting the Laws and Customs of War on Land, 18 October 1907, 36 Stat. 2277, 2 AJIL Supp. 90 (1908), Article 42, the emphasis on factual control rather than legal definition is further evidenced in the remainder of Article 42: "The occupation extends only to territory where such authority has been established and can be exercised."

${ }^{65}$ Wolfrum, Iraq: From Belligerent Occupation to Iraqi Exercise of Sovereignty, 9 MAX PLANCK YEARBOOK OF UNITED NATIONS LAW (2005), 4-5, especially fn. 8., notes the wider scope of Article 2 (2) of the Fourth Geneva Convention which also applies to an occupation meeting no armed resistance; Christopher Greenwood, The Administration of Occupied Territories in International Law, INTERNATIONAL LAW AND THE ADMINISTRATION OF OCCUPIED TERRITORIES: TWO DECADES OF ISRAELI OCCUPATION OF THE WEST BANK AND GAZA STRIP (Emma Playfair ed., 1992), 243.

${ }^{66}$ Wolfrum, Iraq: From Belligerent Occupation to Iraqi Exercise of Sovereignty, 9 MAX PLANCK YEARBOOK OF UNITED NATIONS LAW (2005), 8.

${ }^{67}$ Article 43 of the Hague Regulations leaves little to the imagination in this respect; "The authority of the legitimate power having in fact passed to the hands of the occupant, the latter shall take all measures in his power to restore and ensure, as far as possible, public order and safety, while respecting, unless absolutely prevented, the laws in force in the country." Emphasis added

68 A. Gerson, Trustee-Occupant: The Legal Status of Israel's Presence in the West Bank, 14 HARVARD INTERNATIONAL LAW JOURNAL 1-49 (1978); A. GERSON, ISRAEL, THE WEST BANK AND INTERNATIONAL LAW (1978), 78-82. For a critical discussion of this approach see A. Roberts, What is a Military Occupation?, 55 BRITISH YEARBOOK OF INTERNATIONAL LAW (1984), 292; H.H. Perritt, Jr., Structures and Standards for Political Trusteeship, 8 UCLA JOURNAL OF INTERNATIONAL LAW AND FOREIGN AFFAIRS 385 et seq. (2003); Rüdiger Wolfrum, International Administration in Post-Conflict Situations By the United Nations and Other International Actors, 9 MAX PLANCK YEARBOOK OF UNITED NATIONS LAW (2005), 672-73. 
the belligerent occupant will not possess the legitimacy of brokering a political process in which it can evidently not remain neutral. ${ }^{69}$ The reference to the obvious necessity of political change on which the claims for the revision of the law of occupation are based also confounds the legal nature of occupation. This position seems to infer from the evident necessity to effect socio-political changes that the international law instrument of occupation can no longer be considered comprehensive since it explicitly prohibits such change. But this position confounds an alleged constitutive with the actual prohibitive nature of international humanitarian law according to which occupation:

is a fact recognised and regulated by international law and not an institution created by it. The military occupant derives its power not from international law as such but from the successful projection of military superiority. ${ }^{70}$

The demand is therefore based on the erroneous supposition of the constitutive nature of the law of occupation, while its sole purpose is to proscribe certain types of conduct by the occupant. It must thus be seen as a negative boundary marker very much along the lines of "negative liberties" defined by Berlin with regard to human rights, ${ }^{71}$ i.e. spheres of autonomy protected by legal stipulations against the encroachment of the state. ${ }^{72}$ The purpose of the law is therefore to prevent potential abuse by deliberately limiting the freedom of action of the occupant, not to enable action in the pursuit of lofty ideals:

the occupying power acquires no positive rights stricto sensu within the occupied territory at all, whether to instigate legislative change or craft structural reforms within the occupied territory. The occupying power only acquires responsibilities that are derived from the international legal regulation of this factual situation concerning how the fact of its power can be exercised. ... So in respect of Iraq,

\footnotetext{
${ }^{69}$ H.H. Perritt, Jr., Iraq and the Future of the United States Foreign Policy: Failures of Legitimacy, 31 SYRACUSE JOURNAL OF INTERNATIONAL LAW AND COMMERCE 149 et seq. (2004).

70 McCarthy, The Paradox of the International Law of Military Occupation, 10 JOURNAL OF CONFLICT AND SECURITY LAW (2005), 46, emphasis added; Christopher Greenwood, The Administration of Occupied Territories in International Law, INTERNATIONAL LAW AND THE ADMINISTRATION OF OCCUPIED TERRITORIES: TWO DECADES OF ISRAELI OCCUPATION OF THE WEST BANK AND GAZA STRIP (Emma Playfair ed., 1992), 251.

71 Isaja Berlin, Two Concepts of Liberty, FOUR ESSAYS ON LIBERTY (Isaja Berlin ed., 1969), 129.

72 Negative rights are categorical and absolute rights which "must be respected here and now," D. RAPHAEL, POLITICAL THEORY AND THE RIGHTS OF MAN (1967), 51, 53.
} 
the question in relation to the competence of the occupying powers is, in strict terms, not to what extent do they have a right to institute legislative and institutional reformation, but rather to what extent is their factual capacity to institute reformation constrained by obligations in international law. ${ }^{73}$

This primary role as a negative boundary marker is further underlined by the obvious scepticism that the humiliated population will feel towards the occupant. Legally, the situation couldn't be clearer: "the occupying power [is] to be considered as merely being a de facto administrator. This provision of the Hague Regulations (Art. 43) is not only applicable to the inhabitants of the occupied territory; it also protects the separate existence of the state, its institutions and its laws."74 Policy-wise, the tremendous difficulties encountered in the attempted transformation of Iraq might induce some caution about disregarding the rules in the future.

\section{Alleged Inadequacy of the Law of Occupation}

To avoid reputational costs associated with the rejection of the normative framework of international humanitarian law, the Coalition has maintained that the requirement of abiding by international humanitarian law in respective Security Council Resolutions 1483 and 1511 notwithstanding 75 must be read in conjunction with an alleged mandate for transformation contained therein. On the other hand it has stressed its essentially benevolent motivations which should exempt its actions from being measured against normative constraints developed for less benevolent actors.

The Coalition has thus in effect claimed the legitimacy deriving from international law without accepting the limitations this normative commitment would entail. A twofold rhetorical strategy is deployed: the existence of a mandate implicit in the Security Council resolutions, or, alternatively, the obsolescence of the comprehensive norm, thus necessitating its unilateral modification.

${ }_{73}$ McCarthy, The Paradox of the International Law of Military Occupation, 10 JOURNAL OF CONFLICT AND SECURITY LAW (2005), 46-7, emphasis in the original.

${ }^{74}$ JEAN PICTET (ED.), COMMENTARY ON GENEVA CONVENTION IV OF 1949 (1958), 273.

${ }^{75}$ S/RES/1483 (2003) of 22 May 2003, preamb. para. 13, op. para. 5. 


\section{Limited Mandate}

Due to the purely factual basis of occupation, its legal qualification does not depend on either proclamation by the occupant nor recognition by others. ${ }^{76}$ Nevertheless, the Coalition sought and obtained a recognition by the Security Council. One hoped that this move would increase the legitimacy of the occupation authorities by giving it the possibility to claim a certain international mandate, however limited it might in fact have been. The avowed aim of seeking this alleged mandate "was to evade legal difficulties if the occupying powers sought to move beyond the limited rights conferred by the Hague Regulations and Geneva Convention IV to vary existing arrangements."77 The occupation powers have consistently claimed that they possess adequate authority to administer Iraq by arguing that it is "to be exercised under relevant U.N. Security Council resolutions, including Resolution 1483 (2003), and the laws and usages of war."78 They have thus expressly claimed that Resolution 1483 and 1511 in combination with the laws of war give them a mandate for their policies.

It is clear from the text of the resolutions, as well as from the negotiation history of Resolutions 1483 and 1511 that any move that could be perceived as legitimising the invasion post-fact was to be avoided. Again, the language used in the resolutions is more accurately described as placing limits on the occupation forces than giving it licence for transformation. In particular the rules concerning international financial oversight of the Development Fund for Iraq ${ }^{79}$ were disregarded by the Coalition ${ }^{80}$ underscoring the fundamental incongruity of interests between the occupant and the occupied population. The actual experience with the occupation of Iraq seems thus to advocate, if anything, for placing even stricter limits on the occupant, not loosening available restrictions.

Scheffer argues for the necessity of a more "pragmatic body of rules and procedures than occupation law currently affords," including in situations were multilateral forces are deployed in prolonged occupations aimed at profound societal transformation that

${ }^{76}$ McCarthy, The Paradox of the International Law of Military Occupation, 10 JOURNAL OF CONFLICT AND SECURITY LAW (2005), 45; Benvenisti, Water Conflicts During the Occupation of Iraq, 97 AMERICAN JOURNAL OF INTERNATIONAL LAW (2003), 861-63.

${ }_{77}$ House of Commons, Iraq: Law of Occupation, House of Commons Library Research Paper 03/51, (2003), 25.

78 CPA/REG/16 May 2003/01.

${ }^{79}$ S/RES/1483 (2003) of 22 May 2003, op. paras. 12-14.

${ }^{80}$ See the discussion in $\mathrm{fn} .53$ above. 
do enjoy widespread international support. He posits that such a body of modern occupation law should "accommodate the twin realities of the impact of UN authorization and delegation of responsibilities to military forces deployed into a territory and the international community's intent to transform a society under military occupation." 81 While it is certainly correct that occupation law was never meant to encompass the kind of transformational processes that are the explicit aim of UN peacekeeping operations and UN-mandated enforcement action, ${ }^{82}$ and while a revised body of occupation law is certainly conceivable that takes account of the special requirements of such operations, ${ }^{83}$ the far-reaching transformation necessary in Iraq is largely unsuited to occupation law and could have been dealt with satisfactorily only by a Security Council mandate "setting forth clear responsibilities for deployed forces and a UN-supervised civilian administrative structure" until a legitimate domestic government could have taken over. ${ }^{84}$

Thus as Scheffer himself points out, in cases where there is international consensus, a sui generis Security Council mandate can provide the occupant with the legal instruments to effect the desired changes on behalf of the international community. ${ }^{85}$ But in the absence of such international consensus it is appropriate that occupation law imposes stricter limits ${ }^{86}$ and entails greater potential legal exposure, both in terms of individual culpability and state responsibility. ${ }^{87}$ In the case of an openly hostile, clearly not disinterested occupation, which furthermore does not enjoy clear international support, however, these strictures of occupation law, including the prohibition to change the institutional, legal, and administrative make-up of the state in question

81 Scheffer, Beyond Occupation Law, 97 AMERICAN JOURNAL OF INTERNATIONAL LAW (2003), 84344 .

82 EYAL BENVENISTI, THE INTERNATIONAL LAW OF OCCUPATION (2004), 166-67; Brian D. Tittemore, Belligerents in Blue Helmets: Applying International Humanitarian Law to United Nations Peace Operations, 33 STANFORD JOURNAL OF INTERNATIONAL LAW 61 et seq. (1997).

83 Roberts, What is a Military Occupation?, 55 BRITISH YEARBOOK OF INTERNATIONAL LAW (1984), 302-05.

${ }^{84}$ Scheffer, Beyond Occupation Law, 97 AMERICAN JOURNAL OF INTERNATIONAL LAW (2003), 853.

85 This approach of "outsourcing" the provision of internally-mandated peacekeeping to groups of nation states under unified national command rather than multilateral UN control has been explicitly welcomed in academic and official literature. See Brahimi / et al., Report of the Panel on United Nations Peace Operations, (2000).

86 Scheffer, Beyond Occupation Law, 97 AMERICAN JOURNAL OF INTERNATIONAL LAW (2003), 84344 .

87 Scheffer is, however, quick to assert that "this rather anaemic body of international law remains difficult to enforce against either governments or individuals," Scheffer, Beyond Occupation Law, 97 AMERICAN JOURNAL OF INTERNATIONAL LAW (2003), 857. 
might therefore very well be surprisingly pertinent to the requirements of the modern age.

\section{Obsolescence}

The above claim that a mandate could be implied from said resolutions must be contrasted with the position that neither said resolutions nor the laws of war conferred any legal title or authority but merely recognised a factual situation resulting from military reality. The reference to the law of occupation serves merely to remind the occupant of its responsibilities vis-à-vis the occupied population and, in particular, the limitations on its freedom of action concerning the introduction of institutional and legal changes to the existing state structure. Faced with the charge that it acted ultra vires the occupation powers have adopted an alternative position and rejected the strictures of the law of war as obsolete and open to reinterpretation. The following remarks, while not officially sanctioned, seem indicative of this approach:

one of the things that's distinctive about international actors making changes to international law is that you can just do it. The United States has simply declared that these changes in Iraqi law are legitimate pursuant to international law. There is no one in Iraq to tell us otherwise. ... Basically the international law of occupation is in the process of transformation, and the standard treatises and books on the subject are, I think it is fair to say, obsolete as of now with respect to these questions. 88

\footnotetext{
88 Noah Feldman, Edited Transcript: What We Owe Iraq, 2005, Carnegie Council on Ethics and International Affairs, available at: www.carnegiecouncil.org, emphasis added.

This somewhat nonchalant position is also shared by other legal writers. For instance with respect to the debatable foundation for the establishment of the Iraqi Special Tribunal, one American international lawyer posits two distinct pillars to establish the Tribunal's legitimacy. She alleges that international humanitarian law has evolved since Hague and Geneva and now "recognize[s] the need for an occupying power to be permitted to change the laws of an occupied state in order to render humanitarian aid. This broader interpretation of occupation law under the Geneva Conventions, allowing both occupation and the alteration of an occupied state's laws for humanitarian purposes, would legitimize the IST [Iraqi Special Tribunal] as a judicial institution, despite its formation by an occupying power with or without military necessity." Linda Malone / Christopher M. Rassi / Laura Dickinson, Issue \#3: Is the Iraqi Special Tribunal, which was established on December 10, 2003 by the Occupying Power and the unelected Iraqi Governing Council, a legitimate judicial institution?, 2005, available at: http://law.case.edu/saddamtrial.
} 
The prohibition to introduce political changes into an occupied territory has been criticised as no longer adequate for the kind of military engagements likely to lead to occupation, as they increasingly concern failed or aggressive states where a transformation of its system of governance is the very reason for the military intervention in the first place. ${ }^{89}$ Some have suggested a distinction between a belligerent and a post-surrender occupation, while in the former the prohibition of introducing political changes applies, structural change in the latter would be possible. ${ }^{90}$ It is, however, not at all clear how this position differs from the obsolete doctrine of debellatio, ${ }^{91}$ nor is there any textual basis for such a distinction in either Hague or Geneva law. It is furthermore difficult to square this position with the language of Resolutions 1483 and 1511. ${ }^{22}$

Others who supported the introduction of far-reaching societal and institutional changes have argued that the law of occupation enables the occupant "to wield the totality of sovereign powers that had formerly been vested in the defeated government." This position can hardly be deduced from current international law, as is clearly stated in the US Army Field Manual which these authors proceed to quote, apparently oblivious to contradiction between their position and current international law according to which, as the Manual correctly states, occupation "does not transfer the sovereignty to the occupant, but simply the authority or power to exercise some of the rights of sovereignty." 93

${ }^{89}$ Wolfrum, Iraq: From Belligerent Occupation to Iraqi Exercise of Sovereignty, 9 MAX PLANCK YEARBOOK OF UNITED NATIONS LAW (2005), 8.

${ }^{90}$ As for instance in Germany or Japan. A. Gerson, War, Conquered Territory and Military Occupation in the Contemporary International Legal System, 18 HARVARD INTERNATIONAL LAW JOURNAL (1977).

${ }^{91}$ BENVENISTI, THE INTERNATIONAL LAW OF OCCUPATION (2004), 92-96; McCarthy, The Paradox of the International Law of Military Occupation, 10 JOURNAL OF CONFLICT AND SECURITY LAW (2005), 49; Scheffer, Beyond Occupation Law, 97 AMERICAN JOURNAL OF INTERNATIONAL LAW (2003), 848.

92 "Reaffirming the sovereignty and territorial integrity of Iraq, ...expressing resolve that the day when Iraqis govern themselves must come quickly," S/RES/1483 (2003) of 22 May 2003, preamb. paras. 2 and 4.

"Underscoring that the sovereignty of Iraq resides in the State of Iraq, reaffirming the right of the Iraqi people freely to determine their own political future and control their own natural resources,, reiterating its resolve that the day when Iraqis govern themselves must come quickly", S/RES/1511 (2003) of 16 October 2003, preamb. para. 2.

${ }_{93}$ David B. Jr. Rivkin / Darin B. Bartram, Military Occupation: Legally Ensuring a Lasting Peace, 26 THE WASHINGTON QUARTERLY (2003), 95, 97, emphasis added; Stirk, Carl Schmitt, the Law of Occupation, and the Iraq War, 11 CONSTELLATIONS (2004), 533. 
Logically more consistent, but legally equally questionable is the position expressed by Feldman:

The position of the U.S. government was and is that these laws [enacted by the CPA to effect societal and institutional change] were permissible under international law because they were necessary to accomplish public life and order, ${ }^{94}$ and that they would remain on the books until such time as a legitimate Iraqi government wished to change them. ${ }^{95}$

It is argued, however, that these law enjoyed less than perfect legitimacy, and thereby compromised the overall political reconstruction effort which was based on them. The relative failure of that process attests, if anything, to the continued relevancy of the prohibitions of the law of occupation. The alleged agency for either the Iraqi people or the international community in the pursuit of "freedom" manifestly did not exist in the face of sustained domestic resistance and strong international criticism. As to the claim that an implied mandate must be deemed to have existed because of the evident necessity to alter the unsustainable status quo in Iraq, one cannot but agree with Scheffer who maintains that transformational process in Iraq "requires strained interpretations of occupation law to suit modern requirements. Such unique circumstances are far better addressed by a tailored nation-building mandate of the Security Council." 96

\section{Motivations Matter}

American policy over Iraq can be seen as the result of a long-term change in legal and political perception in which the sacrosanct nature of state sovereignty lost credence in line with the reduction of the systemic need for stability after the end of the Cold War and the perceived analytical and normative shortcomings of the concept. ${ }^{97}$ This essentially liberal intellectual movement, ${ }^{98}$ however, was made

${ }^{94}$ On the validity of that argument see the discussion in Wolfrum, Iraq: From Belligerent Occupation to Iraqi Exercise of Sovereignty, 9 MAX PLANCK YEARBOOK OF UNITED NATIONS LAW (2005), 5; Ebrahim Afsah, Iraq: From "Troubled Law of Occupation" to Constitutional Order? China Shop Rules and International Responsibilities, LEIPZIGER BEITRÄGE ZUR ORIENTFORSCHUNG (2006), 33-36.

95 Noah Feldman, Edited Transcript: What We Owe Iraq, 2005, Carnegie Council on Ethics and International Affairs, available at: www.carnegiecouncil.org, emphasis added.; these statements should not, however, be taken as necessary representing the official US position.

${ }^{96}$ Scheffer, Beyond Occupation Law, 97 AMERICAN JOURNAL OF INTERNATIONAL LAW (2003), 843.

97 Ryan Goodman / Derek Jinks, Toward an Institutional Theory of Sovereignty, 55 STANFORD LAW REVIEW 1749 et seq. (2003). 
possible by the relative demise of realism as the voice of conservative caution and moderation in foreign policy. The reason realism had become the dominant school of thought throughout the Cold War was the premium it placed on stability and maintaining the status quo through the balance of power. It was thus particularly sceptical of moralising crusades, not only because they could have derailed the fragile nuclear peace, but because the theory was based on the realisation that despite their internal differences states as international actors are constrained to behave essentially the same..$^{99}$ With the end of the constraints of the Cold War, other theoretical schools came to dominate, arguing that American primacy now warranted a more activist foreign policy in the pursuit of values, not merely the maintenance of the status quo. Realist voices for caution ${ }^{100}$ became lost influence, and increasingly states were no longer seen as interchangeable systemic actors ${ }^{101}$ but placed along a normatively ranked spectrum on whose polar ends the United States and "rogue states" 102 were respectively placed.

Claims for an activist foreign policy in the pursuit of liberal values were echoed by neo-conservative calls for the active transformation of the international system to enhance American security by transforming hostile powers into friendly ones. ${ }^{103}$ We can thus observe a convergence between two very different intellectual strands that combined to form the policy over Iraq. ${ }^{104}$ Unlike realism, both of these schools

\footnotetext{
98 Reisman, Sovereignty and Human Rights in Contemporary International Law, 84 AMERICAN JOURNAL OF INTERNATIONAL LAW 866 et seq. (1990).

${ }^{99}$ Robert Gilpin, The Richness of the Tradition of Political Realism, NEO-REALISM AND ITS CRITICS (Robert Keohane ed., 1986); KENNETH NEAL WALTZ, THEORY OF INTERNATIONAL POLITICS (1979).

${ }^{100}$ Michael C. Williams, Why Ideas Matter in International Relations: Hans Morgenthau, Classical Realism, and the Moral Construction of Power Politic, 58 INTERNATIONAL ORGANIZATION 633-66 (2004); Barry R. Posen / Andrew Ross, Competing Visions for U.S. Grand Strategy, INTERNATIONAL SECURITY (1996); STEPHEN M. WALT, TAMING AMERICAN POWER: THE GLOBAL RESPONSE TO U.S. PRIMACY (2005).

101 Alexander E. Wendt, The Agent-Structure Problem in International Relations Theor, 41 INTERNATIONAL ORGANIZATION 335-70 (1987).

102 GERRY J SIMPSON, GREAT POWERS AND OUTLAW STATES UNEQUAL SOVEREIGNS IN THE INTERNATIONAL LEGAL ORDER (2004); PETRA MINNEROP, PARIA-STAATEN IM VÖLKERRECHT? (2004).

${ }_{103}$ Michael C. Williams, What is the National Interest? The Neoconservative Challenge in Ir Theory, 11 EUROPEAN JOURNAL OF INTERNATIONAL RELATIONS 307-37 (2005); JOSHUA MURAVCHIK, EXPORTING DEMOCRACY: FULFILLING AMERICA'S DESTINY (1991).
}

${ }^{104}$ James Kurth, Ignoring History: U.S. Democratization in the Muslim World, 49 ORBIS (2005), 310-11. 
of thought consider the internal composition of states to be important determinants of foreign policy, and thus having immediate security implications: ${ }^{105}$

we'll wage a comprehensive strategy to defend our country, and we will use every asset at our disposal. And one of the most powerful assets we have is freedom. Free nations do not breed resentment. Free nations do not export terror. Free nations become allies in the war against terror. By spreading freedom, we help [to] keep the peace. ${ }^{106}$

In this new way of looking at the world ${ }^{107}$ motivations matter. Those of the "other" matter because such states "breed resentment and export terror," but "our" motivations matter, too, because they serve to "spread freedom and keep the peace" and are thus by definition benevolent and benign. With regard to the law of occupation, this differentiation is taken up and the restrictions placed upon the occupant are rejected because they fail to take into account the benevolent intentions of the Coalition. The restrictive nature of the rules of belligerent occupation were designed to prevent the exploitation of a given territory and its inhabitants by a hostile occupant, they are inapplicable in a situation where the external power is in effect the agent of the liberation of the population. It is thereby not only acting on behalf of the liberated populace but the international community as well. While thus technically a belligerent occupant, it is claimed that its benign motivations make it effectively a trustee exercising operational control on behalf of that population, if not the international community. ${ }^{108}$

\section{E. Limiting Power and the Limits of Power}

The above position runs counter to the neutral underpinning of the doctrine which treats occupation as simply a factual matter of actual control, totally divorced from

\footnotetext{
105 Michael N. Schmitt, Preemtive Strategies in International Law, 24 MICHIGAN JOURNAL OF INTERNATIONAL LAW 513-48 (2003).

106 George W. Bush, Remarks by President Bush at Victory 2004 rally, 1 November 2004, 2004, Whitehouse, available at: www.whitehouse.gov/news/releases/2004/11/20041101-24.html.

107 Peter S. Snyder, The Myth of Preemption: More Than a War Against Iraq, ORBIS (2003).

108 Gerson, Trustee-Occupant: The Legal Status of Israel's Presence in the West Bank, 14 HARVARD INTERNATIONAL LAW JOURNAL 1-49 (1978); Perritt, Structures and Standards for Political Trusteeship, 8 UCLA JOURNAL OF INTERNATIONAL LAW AND FOREIGN AFFAIRS 385 et seq. (2003).
} 
the separate issue of ius ad bellum:109 "the question of the legality of the war is separate from the question of the occupation as such."110 Occupation law is agnostic as to the motivations or the alleged legitimacy of the political programme pursued by the occupant, but it starts from the assumption that in the context of an armed conflagration that gives rise to the occupation in the first place it is unlikely to be perceived by the target population as acting in its best interest. Whatever the alleged shortcomings of the law of occupation, we argue that any "process of transformation" cannot simply be put into motion by unilateral fiat: "International law, in principle, does not legitimize the introduction of political changes. ... Stating that such a change may contribute to the restoration of peace does not yet answer whether unilateral actions allegedly pursuing such a purpose conform to existing international law."111

There is an inherent tension between the interests of the occupant of maintaining security and control over the occupied territory, and the desire to restore popular sovereignty, if possible in a democratic setting. ${ }^{112}$ Occupying powers have often found it convenient to reject popular claims for participation with reference to these obligations. ${ }^{113}$ This fundamental conflict of interest is exacerbated in the context of massive nationalistic and religious mobilisation and against the background of a previous war and twelve years of a humiliating and devastating sanction regime imposed by that very occupant.

It has been pointed out that the essence of an occupation regime lies in its selfreferrential and unlimited nature: "Occupation represents not a constitutional government characterised by a balance of powers but rather a sort of emergency government in which all forms of power are concentrated in one centralised body." 114 The CPA has explicitly acknowledged this situation in its Regulation No. 1: "The $\mathrm{CPA}$ is invested with all executive, legislative and judicial authority necessary to

109 Benvenisti, Water Conflicts During the Occupation of Iraq, 97 AMERICAN JOURNAL OF INTERNATIONAL LAW (2003), 861-63.

110 McCarthy, The Paradox of the International Law of Military Occupation, 10 JOURNAL OF CONFLICT AND SECURITY LAW (2005), 48.

111 Wolfrum, Iraq: From Belligerent Occupation to Iraqi Exercise of Sovereignty, 9 MAX PLANCK YEARBOOK OF UNITED NATIONS LAW (2005), 5.

112 For an unsophisticated accocunt that completely disregards this tension see Rivkin / Bartram, Military Occupation: Legally Ensuring a Lasting Peace, 26 THE WASHINGTON QUARTERLY (2003).

113 BENVENISTI, THE INTERNATIONAL LAW OF OCCUPATION (2004), 79.

114 Ernst Fraenkel, Military Occupation and the Rule of Law, GESAMMELTE SCHRIFTEN (Ernst Fraenkel ed., 1999), 3: 211. 
achieve its objectives, to be exercised under relevant U.N. Security Council resolutions, including Resolution 1483 (2003), and the laws and usages of war. This authority shall be exercised by the CPA Administrator."115 The Regulation continues to define its operation, specifying that regulations "shall be those instruments that define the institutions and authorities of the CPA" while orders are its "binding instructions."

The legitimate authority to do all this is simply deemed to exist by reference to the supposedly constituting nature of international law and Security Council resolutions. As we have seen this claim is questionable. An occupation regime ultimately rests on the projection of military power, and is not dependent on the constitutive character of its recognition in international law. The mounting insurgency has exposed fairly drastically the physical limits of the imposition of institutional change by force, and is a powerful reminder of the necessity to be perceived as acting legitimately, not least through abiding by the limitations imposed by the law of occupation.

\section{F. Conclusion}

The question posed by Fraenkel whether occupation law can in principle be limited ${ }^{116}$ has been answered by the protective measures introduced by the Forth Geneva Convention, 117 and it appears that recent experience in Iraq and elsewhere highlights the continued relevance of an objective standard against which to measure abuse. Calls for the alleged inadequacy of occupational law and the unilateral disregard of its rules under the guise of "developing" the law are not only flawed logically and legally, but also make for bad policy.

As a high ranking UN lawyer observes in this regard, one might get away with heavy-handed action because one's physical superiority permits it, but one risks in the process to "win the battle but loose the war." 118 This seems in large measure to be an accurate description of the occupation of Iraq. Simon Chesterman writes: "Modern trusteeships demand, above all, trust on the part of local actors. Earning and keeping that trust requires a level of understanding, sensitivity, and respect for

\footnotetext{
${ }^{115}$ CPA/REG/16 May 2003/01

116 See also Ian Wiliams, Foreign Policy in Focus, 2003, Global Policy, available at: www.globalpolicy.org/security/iraq/attack/law/2003/0514shape.htm.

117 Convention Relative to the Protection of Civilian Persons in Time of War, 12 August 1949, 75 UNTS 287.

118 Mona Ali Khalil, Iraq, Afghanistan, and the War on Terrorism: Winning the Battle and Losing the War, 22 GEORGIA JOURNAL OF INTERNATIONAL AND COMPARATIVE LAW 261-72 (2004).
} 
local traditions and political aspirations that has often been lacking in international administration."119 Few would argue that the occupation possessed these qualities, a fact not entirely lost on the Iraqi public.

119 SIMON CHESTERMAN, YOU, THE PEOPLE: THE UNITED NATIONS, TRANSITIONAL ADMINISTRATION, AND STATE-BUILDING (2004), 257. 